JOURNAL OF SECURITY AND SUSTAINABILITY ISSUES

ISSN 2029-7017 print/ISSN 2029-7025 online

2021 Volume 11

https://doi.org/10.47459/jssi.2021.11.20

\title{
SENSE OF SECURITY AMONG INMATES IN POLISH PRISONS AND DETENTION FACILITIES
}

\author{
Zbigniew Nowacki
}

Academy of Justice, 50 Wiśniowa Street, 02-520 Warsaw, Poland

E-mails: zbigniew.nowacki@swws.edu.pl

Received 5 November 2020; accepted 15 April 2021; published 30 June 2021

\begin{abstract}
The paper considers the feeling of security among inmates in Polish prisons and detention facilities. The adopted methods include the diagnostic survey method, and statistical and comparative analysis method, including factor analysis. The research conducted in five randomly selected Polish prisons and detention facilities included a sample of 392 inmates. Factors significant for the physical and social prison space were analysed. No correlation was found between the sense of security of persons deprived of their liberty and the time spent in a residential cell and the duration of stay and number of transfers in the prison/detention facility. However, it was noted that with the age increase, the "anxiety" of first-time inmates who did not participate in the subculture of prison cryptolect decreased ( $\mathrm{N}=72$, Spearman's rho correlation $=-0.247, \mathrm{p}<0.05$ ) and the "fear of inmates" threatening behaviour" among the prisoners who served a prison sentence again, and who did not participate in the subculture of prison cryptolect, was reduced $(\mathrm{N}=262$, Spearman's rho correlation $=$ $-0.221, p<0.01)$. It was also found that the greater the number of inmates in a residential cell, the lower the "fear of inmates' threatening behaviour" $(\mathrm{N}=48$, Kendall's tau- $b$ correlation $=-0.293, \mathrm{p}<0.01)$ among the participants in the subculture of prison cryptolect who serve a prison sentence again.
\end{abstract}

Keywords: residential cell capacity, variability in the composition of the cell, length of stay in the cell, number of transfers in the prison/ detention facility, age, anxiety and the fear of inmates' threatening behaviour.

Reference to this paper should be made as follows: Nowacki, Z. 2021. Sense of security among inmates in polish prisons and detention facilities. Journal of Security and Sustainability Issues, 11, , 11, 235-243. https://doi.org/10.47459/jssi.2021.11.20

JEL Classifications: Z00

Additional disciplines: safety, security, liberty

\section{Introduction}

Safety, which is an interdisciplinary concept, may be understood as an objective or subjective state. For the purpose of this study, safety is viewed from a psychological perspective. According to R. Klamut: "It is understood as a subjective state of experiencing calmness, security and lack of danger" (Klamut, 2012: p. 48). Further considerations focused on the sense of security, which, according to R. Klamut, is the most important context for understanding safety in psychological terms (ibid). The importance of the need for safety is confirmed by its presence in Maslow's theory. The sole category that is located lower is the physiological needs, which are necessary for sustaining people's biological existence (Maslow, 1990: pp. 62-68). Recognizing the importance of safety, Abraham Maslow states that it is only in extreme situations (war, social disorganization, chronically difficult situations) that safety becomes a dominant factor that motivates to action. However, he identifies individuals (e.g. some neurotics, people suffering from obsessive-compulsive neurosis) whose perception of the world is disturbed, and who may lose this sense of security unexpectedly and relatively easily. Nevertheless, in situations of extreme danger, all people regress from higher needs to the prevailing need for safety. However, this pattern seems to be more pronounced for people living on the verge of safety (ibid. 67-68). The importance 
of the need for safety seems to be linked to its impact - if it is not satisfied, the self-esteem is affected, and so is the perception of the world and the relationship with the surrounding reality (Mądrzycki, 1996: p. 32). According to Siek, the need for safety corresponds to the self-preservation instinct, whereas the deficiency in its satisfaction generates fear and anxiety. (Siek, 1986: p. 126). The feeling of security is the notion which may be a carrier of information about the level of perceived safety. (Klamut, 2012: p. 46). The feeling that, seemingly, might significantly depend on living conditions. However, according to J. Szmyd, it is not only the institution that bears responsibility for the type of internal safety, but also the individual himself/herself, and especially his or her cultural, mental and moral level. In philosophical terms, the quality and standard of the individual's humanization plays a significant role here (Szmyd, 2014: p. 18). According to Z. Uchnast on the other hand, the feeling of security is understood rather as a property at the disposal of a person, which has no reference to the surrounding reality (Uchnast: 1990, pp. 95-108). The quoted opinions clearly highlight the human properties, but they overlook the potential of the impact that environment has on the feeling of security. Andrzej Pieczywok, on the other hand, makes the issue of human safety dependent not only on the complex environmental conditions, but also on the feelings and the ability to assess and understand the changes that take place in the surrounding world and the ability to overcome the experienced difficulties (Pieczywok, 2018: p. 236).

The considerations are related to the feeling of security of adult men deprived of their liberty. They are shaped by their home environment. Thus, they are people with a specific personality structure and a certain culture, which to a large extent determines acceptable defence techniques in difficult situations (Goffman, 1975: p. 155). Perceiving the significance of culture implies an interest in the culture of safety, which Marian Cieslarczyk defines as "a model of basic assumptions, values, norms, rules, symbols and beliefs that influence the perception of challenges, opportunities and/or threats, as well as the way of feeling and thinking about security and the behaviour of the subject that is related to it (Cieslarczyk, 2006: p. 210).

The survey of literature reveals that in a significantly diversified prison population there are prisoners who have a destructive effect on their co-prisoners (Kamiński, 2006: pp. 254-257; Nowacki, 2011: pp. 62-64). As a result of the inspection: Safety of inmates (P/19/040), conducted by the Supreme Audit Office, as of 28.10.2019 in Polish closed-type prisons, there were 85 cells with a capacity of more than ten inmates (the largest 18 -person cell was located in a detention facility in Białystok $)^{1}$. The inspection in question also found that the problem of conditions in multi-person cells was addressed by the Ombudsman in his speech of 22 November $2018^{2}$, who noted that incarceration of persons who have problems controlling their emotions implies they are under increasing tension and stress ${ }^{3}$. However, it would be an oversimplification to say that a sense of threat can only be aroused in a residential cell. A person deprived of their liberty may also feel threatened in places of temporary residence and while moving around the prison (more broadly: Nowacki, 2011: pp. 63-74; Nowacki, 2012: pp. 93- 106).

The experience of prison isolation means that existing ties are broken and a process of degrading human personality begins. Some fundamental changes to moral attitudes and changes in beliefs take place. Human behaviour is governed by the principle of maximising one's own interests. An inmate respects only the opinions of significant people in the prison community (Goffman, 1975: p. 155). In relations with prison staff, however, inmates reveal inclinations to ingratiation (Nowacki, 2017: pp.141-143). Many researchers convince that ingratiation institutions exist (Goffman, 1981; pp. 306-310, 321; Grzywa, 2010: p. 74, 81-82).

It seems that the factors that may remain in relation to the feeling of security of persons deprived of their liberty should be viewed in two main areas. The first area seems to be filled by the 'properties' of a person deprived of their liberty, which may affect relations with prisoners, namely: caste affiliation, personal characteristics, age, behaviour (especially in prison isolation), the nature of the offence, the end date of imprisonment. The second area contains physical and social aspects of the situational context of imprisonment, which may affect the rela-

\footnotetext{
1 Supreme Audit Office, Information on the results of the inspection SAFETY OF INMATES, https://www.nik.gov.pl/plik/ id,22869,vp,25572.pdf, p. 36, access: 15.10.2020.

2 Ref. no. IX.517.599.2017.PM

3 Supreme Audit Office, Information on the results of the inspection SAFETY OF INMATES, https://www.nik.gov.pl/plik/ id,22869,vp,25572.pdf, p. 37, access: 15.10.2020.
} 
tions in prison community. The primary environment seems to be of particular importance, i.e. the residential cell, which is characterised by: capacity, variability in the composition of the cell, length of stay in the cell, but also a caste system which expresses a relative strength of subgroups in the prison population and the physical location in the establishment (including the pavilion and ward and the location within the ward). In addition, it can be presumed that the factors of the first area determine the inmate's relationships in the second area to a varying degree. To a varying degree - because their interpretation is made by the personal composition of the relevant cell and may take into account the local component and the transformations of the historical period. The areas identified as certain entities, while remaining in a relationship, can shape prison interactions and, as a response to the behaviour of a person deprived of their liberty, influence their feeling of security.

According to Barbara Szacka, society is not an autonomous and external whole in relation to the behaviour (actions) of human individuals. For people, it is (the most often) a network of individual meetings and connections (Szacka, 2003: p. 123). The prison community is a community that operates in a very limited space. The essence of meetings and prison relationships outside a residential cell are expressed by such terms as surveillance, control, restrictions and superficiality. These meetings and relationships, often so desired (by inmates), on other occasions arousing a sense of threat - are practically unavoidable.

The aim of the presented studies ${ }^{4}$ is to try to identify factors that may be related to the feeling of security of adult male inmates in Polish prisons and detention facilities. The present study analyses the feeling of security that is dependent on the behaviour of co-prisoners.

\section{Methodological assumptions of the author's own research}

In order to achieve the research objective, a diagnostic survey method and statistical and comparative analysis methods were used. The survey technique and the interview technique were used in accordance with the adopted method. The basic research tool was the author's own Sense of Security Questionnaire for Persons Deprived of their Liberty, which consisted of questions used to determine the level of inmates' security. The respondents answered questions with the use of the 4 point Likert scale. High results indicate a low sense of security (high sense of threat). The Mood of the inmates was also controlled, and the Lie Scale was used, which consisted of five items similar to the questions of verification scales from personality inventories, mainly the 'Lie scale' from Eysenck's MPI (Choynowski 1968(2), pp. 51-95, Drwal 1981, pp. 144-145). An integral part of the study was to obtain classification information necessary for a statistical analysis of the obtained data from a proper correction officer. The information was arranged and recorded in the Personal-Cognitive Documentation Card.

The research was carried out in five randomly selected Polish organisational units of the Prison Service, namely: Detention Facility in Radom ( $N=67,17.1 \%)$; Detention Facility in Kielce ( $N=105,26.8 \%)$; the External Branch of the Detention Facility in Grójec (N=90, 23\%); Correctional Facility in Krzywaniec (N=68, 17,3\%); Correctional Facility No.1 in Wrocław (N=62, 15,8\%). The group of respondents comprised a total of 392 adult men imprisoned in closed-type $(\mathrm{N}=220,56.1 \%)$ and half-open type $(\mathrm{N}=172,43.9 \%)$ correctional facilities. Random sample selection was used. Participation in the research was voluntary. The respondents were provided with detailed instructions, including the need to consider before giving an answer. Inmates were informed that they could resign from the participation in the study at any stage. The adequate investigator-researcher quality was ensured. The study was concluded with an interview with the inmate during which the respondent had the opportunity to obtain answers to his questions, including those concerning the purpose of the study, his participation in the study, the results obtained and their significance. Ultimately, the statistical analysis was performed on the results of 334 adult men who did not participate in the subculture of prison cryptolect $(82.5 \%)$ and 58 participants of the subculture of prison cryptolect $(14.8 \%)$. The imprisoned men were studied in three age groups: early adulthood ( $\mathrm{N}=118$, $\mathrm{SD}=2.86, \mathrm{M}=25.81,30.1 \%)$; medium adulthood $(\mathrm{N}=265, \mathrm{SD}=6.65, \mathrm{M}=40.2,67.6 \%)$; late adulthood $(\mathrm{N}=9$, $\mathrm{SD}=4.2, \mathrm{M}=64.67,2.3 \%$ ). The education of persons deprived of their liberty was varied (primary $-30.6 \%$; lower secondary $-19.9 \%$; basic vocational $-30.9 \%$; secondary $-16.8 \%$; higher $-1.8 \%$ ).

4 Nowacki Z. Poczucie bezpieczeństwa osadzonych w polskich jednostkach penitencjarnych, [Sense of security of inmates in Polish penitentiary institutions], IBR WSKiP in Warsaw, a thesis under the supervision of prof. Beata Maria Nowak, Warsaw 2020. 


\section{Verification of the research tool of own construction - Sense of Security Questionnaire for Persons Deprived of their Liberty in the Transition Cell}

With the use of factor analysis by the principal component method, the KMO values for each of the 18 questions included in the author's questionnaire were defined, verifying whether they are consistent enough with the remaining questions of the tool, so that they could be left in the analysis. All questions obtained satisfactory individual KMO measurement properties. The measure of sampling adequacy for the whole sample (all questions) reached a fully acceptable $\mathrm{KMO}=0.935$, which means that the sampling was satisfactory for analysis. The Barlett's Test of Sphericity $\left[\mathrm{Chi}^{2}(465)=5554.769 ; \mathrm{p}<0.001\right]$ showed that the correlations between the individual factors were large enough to carry out factor extraction (Bedyńska, Brzezicka, 2007).

Both the scree plot and the Kaiser criterion indicated a two-factor solution, which explained the total of $42.11 \%$ of the variance. This means that taking into account the explorative approach to the created tool for measuring the Sense of Security Among Inmates in Polish Prisons and Detention Facilities, the answers were treated as referring to two clearly separable factors. The Varimax method was used for the extraction of factors. The first extracted factor, called "fear of inmates' threatening behaviour", contains questions implying that one of the security factors may be the behaviour of fellow inmates, e.g.: Q19: Do you feel threatened while taking a walk? This factor explains $35.12 \%$ of the variance. The second factor is called 'anxiety' because it contains questions indicating that anxiety about continuing to stay in prison may be a security factor, e.g. Q10: Has any prisoner warned you about any threat from prisoners? This factor explains $6.99 \%$ of the variance.

In order to determine the level of reliability (reliability understood as a feature that indicates the accuracy of measurement) of the questionnaire, Cronbach's Alpha statistics were calculated. All factors are characterised by satisfactory reliability (for the factor "fear of inmates' threatening behaviour", consisting of 11 items: P2, P5, P6, P19, P20, P32, P34, P35, P36, P38, P41 - $\alpha=0$,887; for the factor "anxiety", consisting of 7 items: P1, $\mathrm{P} 8, \mathrm{P} 9, \mathrm{P} 10, \mathrm{P} 11, \mathrm{P} 14, \mathrm{P} 16-\alpha=0,720$.

Statistical measurements for the factor "fear of inmates' threatening behaviour" showed that this factor was characterised by moderate variation $(\mathrm{N}=392, \mathrm{M}=1.302, \mathrm{SD}=0.382)$. To check the normality of the distribution of results the Kolmogorov-Smirnov test was used. The statistics and the significance for this test showed that the data distribution was not consistent with normal distribution (K-S=0.214, $\mathrm{p}<0.001)$. The skewness statistic $(\mathrm{SK}=1.943)$ indicated a significant positive right-skewed distribution, i.e. the predominance of values higher than the mean, while the kurtosis statistic $(K U=4.530)$ indicated significant leptokurtic distribution, i.e. a concentration of the results around the mean.

The "anxiety" factor was characterized by a moderate differentiation ( $\mathrm{N}=392, \mathrm{M}=2.132, \mathrm{SD}=0.536)$. The factor distribution was not consistent with normal distribution $(\mathrm{K}-\mathrm{S}=0.087, \mathrm{p}<0.001)$. The skewness statistic indicated a slightly right-skewed distribution, i.e., a predominance of values higher than the mean $(\mathrm{SK}=0.332)$, while the kurtosis statistic indicated a slightly platykurtic distribution, i.e., a small concentration of results around the mean and a lot of extreme results $(\mathrm{KU}=-0.278)$.

To check if there is a correlation between the factors, a correlation analysis was performed. A non-parametric Spearman rho correlation test was used. The coefficients indicate that with the increase in the "fear of inmates' threatening behaviour" factor, the "anxiety" factor increases strongly ( $\mathrm{N}=392$, Spearman's rho correlation $=0.487, \mathrm{p}<0.01$ ). With the increase in the "anxiety" factor, the "fear of inmates' threatening behaviour" factor increases strongly ( $\mathrm{N}=392$, Spearman's rho correlation $=0.487, \mathrm{p}<0.01)$.

In order to analyse the relationship between the "mood" factor and the feeling of security of men deprived of their liberty, the non-parametric Kendall's tau- $b$ correlation test was applied. All correlations, i.e.: between the "mood" factor and the "fear of inmates' threatening behaviour" factor (Kendall's tau- $b$ correlation -0.119 , $\mathrm{p}<0.01$ ), and between the "mood" factor and the "anxiety" factor (Kendall's tau- $b$ correlation $-0.093, \mathrm{p}<0.05$ ) 
were statistically significant. Low values of correlation coefficient should be interpreted as no correlation or very weak correlation (Bedyńska, Cypryańska, 2013: p. 201). It can therefore be concluded that the results of the study are reliable.

In order to verify the relationship between the result on the Lie Scale and the identified factors, the non-parametric Kendall' tau- $b$ correlation test was used. Only the correlation between the result on the Lie Scale and the "anxiety" factor was statistically significant (Kendall's tau-b correlation $-0.250, \mathrm{p}<0.01$ ). The low value of the correlation coefficient should be treated as a very weak correlation between variables (ibid.). Hence the conclusion, that the study outcomes are reliable.

\section{Study outcomes}

The most important research findings are as follows. It was noted that with the age increase, the "anxiety" of first-time inmates who did not participate in the subculture of prison cryptolect decreased ( $=72$, Spearman's rho correlation $=-0.247, \mathrm{p}<0,05)$ and the "fear of inmates' threatening behaviour" among the inmates who served a prison sentence again, and who did not participate in the subculture of prison cryptolect, was reduced $(\mathrm{N}=262$, Spearman's rho correlation $=-0.221, \mathrm{p}<0.01)$.

In order to verify the relationship between the number of incarcerated persons in a residential cell and the feeling of security, Kendall's tau- $b$ correlation test was applied. In the case of first-time prisoners, there was no correlation between the size of the residential cell and the feeling of security. However, in the case of prisoners serving a prison sentence again, who did not participate in the subculture of prison cryptolect, the correlation coefficient indicates that the larger the capacity of cells, the lower the "fear of inmates' threatening behaviour". $(\mathrm{N}=262$, Kendall's tau-b correlation=-0.191, $\mathrm{p}<0.01)$ and lower the "anxiety" $(\mathrm{N}=262$, Kendall's tau- $b=-0.178, p<0.01)$. However, in the case of prisoners serving a prison sentence again, who participate in the subculture of prison cryptolect, the correlation coefficient indicates that the greater the number of prisoners in a residential cell, the lower the "fear of inmates' threatening behaviour" ( $N=48$, Kendall's tau-b correlation $=-0.293, \mathrm{p}<0.01)$.

A correlation analysis was carried out to check whether there is a correlation between the variability in the composition of a residential cell and the feeling of security. In the case of prisoners serving a prison sentence again, who do not participate in the subculture of prison cryptolect, the correlation coefficient indicates that the greater the variability in the composition of the residential cell, the lower the "fear of inmates' threatening behaviour" $(\mathrm{N}=262$, Spearman's rho correlation=-0.167, $\mathrm{p}<0.01)$. No more relationships between the variability in the composition and the feeling of security were found.

It was noted that the number of transfers within the prison / detention facility (the facility in which the inmate currently stays) is not related to the feeling of security of adult men deprived of their liberty. Nor is there any correlation between the length of time spent in a residential cell and the feeling of security of adult men deprived of their liberty.

On the other hand, there is a weak, positive relationship between the time left until the end of the sentence among the inmates serving prison sentence again, who do not participate in the subculture of prison cryptolect and the "anxiety" factor ( $\mathrm{N}=262$, Spearman's rho correlation=0.161, $p<0.01$ ). The more time until the end of the sentence, the greater the "anxiety" of the inmates serving a prison sentence again, who do not participate in the subculture of prison cryptolect. No more correlations were found between the time left in prison and the feeling of security.

A correlation analysis was carried out to see if there is a correlation between the time spent in prison / detention facility (unit in which the inmate currently stays) and feelings of security. There is no correlation between the length of time spent in a prison / detention facility and the feeling of security among adult men deprived of their liberty. 


\section{Conclusions}

1. With the age increase, the "anxiety" of first-time inmates who do not participate in the subculture of prison cryptolect decreased, and so did the "fear of inmates' threatening behaviour" among the inmates who serve a prison sentence again, and who do not participate in the subculture of prison cryptolect.

2. The length of stay in a residential cell and the number of transfers in the prison / detention facility does not relate to the feeling of security among adult men deprived of their liberty.

3. The remaining time of imprisonment is not related to the feeling of security of first-time inmates in prison isolation and participants of the prison subculture. However, the more time until the end of the sentence, the greater the "anxiety" of the inmates serving a prison sentence again, who do not participate in the subculture of prison cryptolect.

4. The capacity of a residential cell is not related to the feeling of security of those in prison isolation for the first time. On the other hand, the larger the capacity of cells, the lower the "fear of inmates' threatening behaviour" and the lower the "anxiety" of inmates serving prison sentence once again, who do not participate in the subculture of prison cryptolect. It was also noted that the greater the number of inmates in a residential cell, the lower the "fear of inmates' threatening behaviour" among the participants in the subculture of prison cryptolect who serve a prison sentence again.

5. The variability in the composition of a residential cell is not related to the feeling of security of those in prison isolation for the first time. On the other hand, the larger the variability in the composition of cells, the lower the "fear of inmates' threatening behaviour" among the inmates serving prison sentence once again, who do not participate in the subculture of prison cryptolect.

The study presented in this paper analyses the relationships between the feeling of security among persons deprived of their liberty and the variables distinguished by means of factor analysis. The previously indicated multiplicity of factors that might be related to the feeling of security among persons deprived of their liberty did not facilitate the research work. This makes the results even more interesting.

The findings with regard to the relationship between the capacity of the residential cell and the feeling of security among persons deprived of their liberty do not corroborate the conviction of Marek Kamiński (2006), who believes that it is in larger cells that the subculture 'flourishes' (Kamiński, 2006: p. 255). The apparent contradiction disappears, however, when we notice that Marek Kamiński's conviction refers to the cells in which more than ten inmates were imprisoned. On the other hand, the presented results refer to the residential cells of much lesser capacity (the median value is 4.0 and $92.1 \%$ of the respondents were in six-person or smaller cells). The obtained result leads to reflections on the optimal (for the prisoners' feeling of security) capacity of a residential cell. The research also revealed that a greater variability in the composition of the cell is related to the lower "fear of inmates' threatening behaviour" among men serving prison sentence again, who do not participate in the subculture of prison cryptolect. The research result seems to justify the need for a variation in the personal composition of residential cells. The result becomes more significant when we compare it with the lack of correlation between the length of time spent in a residential cell and the feeling of security of persons deprived of their liberty. This need to 'refresh' the composition of residential cells - so disliked by persons deprived of their liberty - can, in fact, be related with a feeling of security. On the other hand, this seems to prevent the implications of "settling into the residential cell" among inmates (which in the case of harmonised two-person cells may be difficult to reveal). This is a noteworthy postulate, as the research results indicate that there is no correlation between the feeling of security among persons deprived of their liberty and the number of transfers within an organisational unit of the Prison Service and the length of time spent in prison / detention facility. The proposal does not contradict my position on the frequency of the inmates' transfers within organisational units but it complements it with the need to take into account the inmates' feeling of security (Nowacki, 2010: pp. 127-129). 
According to Szmyd, a person's safety also depends on the person themselves (Szmyd, 2014: p. 18). Jan Szmyd also recognises the capacity of institutions to model and organise collective and individual life (ibid.). The above statement leads to the formulation of two demands for the sake of security of persons deprived of their liberty. The first boils down to intensifying actions aimed at making inmates aware that their security also depends on them. The second demand refers to equipping inmates with instructions to assist them in their struggle against the threat from other prisoners. It is assumed that it would be good to take care of sensitising them to the influence of others and the ability to predict the consequences of their own behaviour.

The above considerations direct attention to educational activities and their important goal - shaping a culture of safety. According to Anthony Giddens: "A culture of safety implies a certain 'safe' way of life, which consists in daily, mostly thoughtless activities that result from 'practical awareness' and creative activities that result from 'thoughtless awareness' (in: Mamzer, 2008: p. 23). As Fehler points out, a significant portion of the situations a person may be involved in are simply challenges (e.g. uncertain situations) that can be made safe by mobilising forces and intensifying thoughtful action (Fehler, 2018, p. 33). Bernard Wiśniewski, on the other hand, notes that the condition for the development of any society is to ensure its safety to the greatest extent possible (Wiśniewski, 2018, p. 218). He also stresses the key role in the creation of appropriate attitudes and values, and the acquisition of skills in the area of counteracting the dangers of education for safety (ibid., p. 209). The statement seems to justify the postulate of activating people deprived of their liberty to shape a culture of safety.

\section{References}

Bedyńska S., Brzezicka A. (2007). Statystyczny drogowskaz [Statistical signpost]. Warsaw: Wydawnictwo SWPS Academica.

Bedyńska S., Cypryańska M. (2013). Statystyczny drogowskaz 1. Praktyczne wprowadzenie do wnioskowania statystycznego [Statistical signpost 1. A practicalintroduction to statisticalinference]. Warsaw: Wydawnictwo Akademickie Sedno, Szkoła Wyższa Psychologii Społecznej.

Choynowski M. (1968). Opracowanie polskiej adaptacji „Inwentarza osobowości” H. J. Eysenecka (MaudsleyPersonality Inventory) [Polishadaptation of H. J. Eysenck's 'Personalityinventory' (MaudsleyPersonality Inventory)]. Biuletyn Psychometryczny, no. 2, pp. 51-95.

Cieslarczyk M. (2006). Kultura bezpieczeństwa i obronności [The culture of safety and defence]. Siedlce: Wydawnictwo Akademii Podlaskiej.

Ciosek M. (2001). Psychologia sądowa i penitencjarna [Forensic and penitentiarypsychology]. Warsaw: Wydawnictwa Prawnicze PWN.

Drwal R., Ł. (1981). Osobowość wychowanków zakładów poprawczych [Personality of youthdetentioncentreinmates]. Wrocław, Warszawa, Kraków, Gdańsk: Zakład Narodowy im. Ossolińskich Wydawnictwo Polskiej Akademii Nauk.

Fehler W. (2018). Percepcjazagrożeń [Perception of threats]. In: B. Wiśniewski (ed.), Bezpieczeństwo w teorii i badaniach naukowych. Wydanie II uzupełnioneiuaktualnione [Safety in theory and academic research. Edition II - supplemented and updated] (pp. 30-38) Szczytno. Wydawnictwo Wyższej Szkoły Policji w Szczytnie.

Goffman E. (1975). Charakterystyka instytucji totalnych, [Characteristics of totalinstitutions] In: W. Derczyński, A. Jasińska-Kania, J. Szacki (ed.), Elementy teorii socjologicznych. Materiały do dziejów współczesnej socjologii zachodniej [Elements of sociologicaltheories. Materials to the history of modern Western sociology] (pp.150-177). Warsaw: WydawnictwoNaukowe PWN.

Goffman E. (1981). Człowiek w teatrzeżyciacodziennego [The Presentation of Self in Everyday Life]. Warsaw: PIW.

Grzywa A. (2010). Manipulacjaczylipoznajmechanizmypsychologicznewywieraniawpływu [Manipulation - learn psychological mechanisms of exerting influence]. Kraśnik: Wydawnictwo Psychologia Sukcesu.

Kamiński M. (2006). Gry więzienne. Tragikomiczny świat polskiego więzienia [Prisongames. Tragic and comic world of the Polish prison]. Warsaw: OficynaNaukowa.

Klamut R. (2012). Bezpieczeństwo jako pojęcie psychologiczne [Safety as a psychologicalnotion]. Zeszyty

Naukowe Politechniki Rzeszowskiej: Ekonomia i Nauki Humanistyczne, no. 19/4, pp. 41-51. 
Mamzer H. (2008). Poczucie bezpieczeństwa ontologicznego. Uwarunkowaniaspołeczno - kulturowe [The feeling of ontological security. Social and cultural conditioning]. Poznań: Wydawnictwo Naukowe UAM.

Maslow A. (1990). Motywacja i osobowość [Motivation and personality]. Warsaw: Instytut Wydawniczy PAX.

Mądrzycki T. (1996). Osobowość jako system tworzący i realizujący plany [Personality as a system thatcreates and implementsplans]. Gdańsk: Gdańskie Wydawnictwo Psychologiczne.

Nowacki Z. (2010). Wywieranie wpływu społecznego w warunkach izolacji więziennej [Exertingsocial influence in the conditions of prisonisolation]. Kraków: Oficyna Wydawnicza „Impuls”.

Nowacki Z. (2011). Wypadki nadzwyczajne w warunkach izolacji więziennej w świetle teorii uczenia się [Extraordinaryevents in the conditions of prisonisolation in the light of the theory of learning]. Przeglad Więziennictwa Polskiego, no. 70, pp. 64-68.

Nowacki Z. (2012). Autoagresja w warunkach izolacji więziennej - nie tylko funkcjonalne aspekty zachowania [Auto-aggression in the conditions of prisonisolation - (not only) functionalaspects of behaviour]. Przeglad Więziennictwa Polskiego, no. 74-75, pp. 83-108.

Nowacki Z. (2017). Skłonność skazanych do ingracjacji [Inmates' inclinationtowardsingratiation]. ResocjalizacjaPolska, no. 13, pp. 123-145.

Nowacki Z. Poczucie bezpieczeństwa osadzonych w polskichjednostkachpenitencjarnych [Sense of security among inmates in Polish penitentiary institutions], an unpublished final report of the Research and Development Institute of the Higher School of Criminology and Penitentiary Science in Warsaw, a thesis under the supervision of prof. Beaty Marii Nowak, Warsaw 2020.

Pieczywok A. (2018) Kulturowo-społeczne uwarunkowania edukacji dla bezpieczeństwa [Cultural and socialconditioning of education for safety]. In: Bezpieczeństwo w teorii i badaniach naukowych. Wydanie II uzupełnioneiuaktualnione [Safety in theory and academic research. Edition II - supplemented and updated] (pp. 232-244). Szczytno. Wydawnictwo Wyższej Szkoły Policji w Szczytnie.

Siek S. (1986). Struktura osobowości [Structure of personality]. Warsaw: ATK.

Snopek M. (2013). Przyczyny degradacji skazanych poszkodowanych w realiach polskich więzień [Reasons for the degradation of inmates in the realities of Polishprisons]. Resocjalizacja Polska, No. 5, pp. 167-182.

Snopek M. (2019). Zagrożenie bezpieczeństwa osadzonych w przestrzeni izolacji więziennej [Threat to inmates'safetywithin the confines of prisonisolation]. AnnalesUniversitatisMariae Curie-Skłodowska. Sectio J Pedagogia-Psychologia, No. 3, pp. $273-288$.

Szacka B. (2003). Wprowadzenie do socjologii [Introduction to sociology]. Warsaw: Oficyna Naukowa.

Szmyd J. (2014). Poczucie bezpieczeństwa jako wartość społeczna, etyczna i egzystencjalna. Rozważaniapodstawowe. [Feeling of security as a social, ethical and existential value. Basic considerations.] PaństwoiSpołeczeństwo (XIV) No. 2, pp. 9-19.

Uchnast Z. (1990). Metodapomiarupoczuciabezpieczeństwa [A method of measuring the feeling of security]. In: A. Januszewski, Z. Uchnast, T. Witkowski (red.), Wykładypsychologii w KUL [Lectures in psychology at the Catholic University of Lublin] (Vol. 5; pp. 95-108). Lublin: Wydawnictwo KUL Kraków.

Wiśniewski B. (2018). Edukacja dla bezpieczeństwa wobec teorii i praktyki kształcenia [Education for safety with regard to the theory and practice of education]. In: Wiśniewski B. (ed.), Bezpieczeństwo w teorii i badaniach naukowych. Wydanie II uzupełnioneiuaktualnione [Safety in theory and academic research. Edition II - supplemented and updated] (pp. 209-232). Szczytno. Wydawnictwo Wyższej Szkoły Policji w Szczytnie.

\section{Legal sources}

The ordinance of the Minister of Justice of 21 December 2016 on the regulations governing the organization and orderly execution of imprisonment (Journal of Laws, item 2231).

The Act of 6 June 1997 - The Penal Code (Journal of Laws from 1997, no 88, item. 553, as amended)

The Act of 6 June 1997 - The Executive Penal Code (Journal of Laws No 90, item 557, as amended.).

Guidelines No. 1/2019 of the General Manager of the Prison Service on the technical and protective requirements for pavilions where prisoners are accommodated in organisational units of the Prison Service.

Order No. 19/2016 of the General Manager of the Prison Service of 14 April 2016 on the detailed rules of conducting and organising penitentiary work, as well as the scope of activities of officers and employees of penitentiary and therapeutic departments and penitentiary wards. 


\section{Electronic documents}

Cells for more than 10 people to be liquidated. Prison Service agrees with the Ombudsman, available online: https://www.rpo.gov.pl/pl/ content/cele-ponad-10-osobowe-do-likwidacji-sluzba-wiezienna-przyznaje-racje-rpo [accessed: 23 August 2020].

Information on the situation of the elderly in Poland for the year 2018, The Ministry of Labour, Family and Social Affairs, Warsaw 2019, available online: https:// www.gov.pl [accessed: 27 June 2020].

Supreme Audit Office, Information on the results of the inspection SAFETY OF INMATES, https://www.nik.gov.pl/plik/id,22869,vp,25572. pdf.

Response to the speech IX.517.599.2017.PM of 22 November 2018 on the liquidation of all residential cells for more than ten people in closed-type penitentiary institutions. BDG.055.11.2018.AŚB dated 19.12. 2018, available online:https://www.rpo.gov.pl/sites/default/ files/Odpowied\%C5\%BA\%20SW\%2019.12.2018.pdf [accessed:23 August 2020].

Zbigniew NOWACKI doctor of humanities, assistant professor at Academy of Justice in Warsaw, prison officer at the penitentiary. ORCID ID: https://orcid.org/0000-0002-0443-7117

Register for an ORCID ID:

https://orcid.org/register

This work is licensed under the Creative Commons Attribution International License (CC BY). http://creativecommons.org/licenses/by/4.0/ 